\title{
A hypothesis for the composition history of Paul's Second Letter to the Corinthians
}

\author{
Author: \\ Gert J.C. Jordaan ${ }^{1}$ \\ Affiliation: \\ ${ }^{1}$ Faculy of Theology, \\ North-West University, \\ Potchefstroom Campus, \\ South Africa \\ Correspondence to: \\ Gert Jordaan \\ Email: \\ 10184120@nwu.ac.za \\ Postal address: \\ PO Box 20103 \\ Noordbrug 2522, \\ South Africa \\ Dates: \\ Received: 22 Nov. 2013 \\ Accepted: 18 June 2014 \\ Published: 17 Dec. 2014 \\ How to cite this article: \\ Jordaan G.J.C., 2014, \\ 'A hypothesis for the \\ composition history of \\ Paul's Second Letter to the \\ Corinthians', In die Skriflig \\ 48(1), Art. \#1783, 9 pages. \\ http://dx.doi.org/10.4102/ \\ ids.v48i1.1783

\section{Copyright:} \\ (C) 2014. The Authors. \\ Licensee: AOSIS \\ OpenJournals. This \\ work is licensed under \\ the Creative Commons \\ Attribution License.
}

Read online:

Scan this QR

code with your

smart phone or

mobile device

to read online.
The abrupt transitions and incoherent passages in 2 Corinthians led some scholars to believe that the letter originated from a composition of a number of documents. There are also scholars who try to solve the problem by harmonising the obviously incoherent passages of the letter. In this article, a different solution is proposed, namely that 2 Corinthians was written by Paul not at one occasion but over a longer period of time with several intervals. Paul probably wrote the letter in different phases whilst travelling from Ephesus to Corinth on his third missionary journey.

‘n Hipotese vir die ontstaansgeskiedenis van Paulus se tweede brief aan die Korinthiërs. Die abrupte oorgange en onsamehangende gedeeltes in 2 Korintiërs het sommige biblioloë oortuig dat die brief uit 'n samestelling van verskeie korter briewe ontstaan het. Daar is ook biblioloë wat die gebrek aan samehang probeer omseil deur die onsamehangende briefgedeeltes in harmonie met mekaar te bring. In hierdie artikel word 'n ander oplossing vir die probleem aangebied, naamlik dat 2 Korintiërs nie by een geleentheid nie, maar oor 'n langer tydperk met verskeie tussenposes deur Paulus geskryf is. Die apostel het waarskynlik die brief in verskillende fases geskryf tydens sy derde sendingreis van Efese na Korinte.

\section{Background and basic theoretical statement}

The second letter to the Corinthians, as we know it in the Canon, is notorious for its lack of a coherent and logical argumentative build-up (cf. Coetzee 1995:40; Guthrie 1990:457; Kümmel 1972:206). The letter is characterised by abrupt transitions and incoherent passages. Especially 2 Corinthians 7:4-5 and 9:15-10:1 are generally singled out as passages with such abrupt transitions (cf. McCant 1999:20; Thrall 2004:4). As a result, the unity or integrity of the letter has been under scholarly suspicion for the last two centuries. The first to air this suspicion was the German scholar J.S. Semler, who in 1771 suggested that 2 Corinthians is a composition of three earlier letters, chapters 1-8 (plus 13:11-13), chapter 9 and chapters 10-13:10, to the present letter (Plummer 1925:xxix).

Since Semler's work a variety of theories have been developed (cf. Thrall 2004:47-49), namely a two-letter theory (e.g. Lake 1919; Plummer 1925), a three-letter theory (e.g. Vielhauer 1975:153), a four-letter theory (e.g. Bornkamm 1962; Georgi 1964:24), a six-letter theory (Schmithals 1969:9094) and even a nine-letter theory (Weiss 1970). Of these perhaps the most popular is the theory of Adolf Hausrath, which became known as 'the four-letter hypothesis' (cf. McCant 1999:20): Chapters 1:1-2:13, continued in 7:5-16 (and 13:11-13); Chapters 2:14-7:4; Chapter 8 (and 9); Chapters 10-13:10 (or 13:13). The last four chapters (10-13) are identified with Paul's 'tearful letter' (2:3-4).

These hypotheses were based not only on the abruptness of transitions in 2 Corinthians, but also on the following features of the letter:

1. There are historical discrepancies between the separate sections of the letter. For example, in chapter 8 , it is clear that Titus still has to arrive in Corinth ( $\dot{\varepsilon} \xi \tilde{\eta} \lambda \theta \varepsilon v$ in $8: 17$ being taken as an epistolary aorist, cf. Grosheide 1959:241) whereas chapter 12:17-18 provides evidence that Titus is already at work in Corinth (cf. Thrall 2004:6).

2. The first person plural is mostly used in chapters $1-9$, but chapters $10-13$ switches to the first person singular (cf. Thrall 2004:6).

However, there are scholars who continue to defend the unity of 2 Corinthians. Amongst them are Bates (1965), Coetzee (1995), Guthrie (1990), Hughes (1962), Kümmel (1972), Lategan (1984) 
and Matera (2003). Arguments, which they use against the composition theory, are inter alia the following:

1. The change in tone between chapters 1-9 and 10-13 was intentional. Long (2004:178) contends that the switch was part of Paul's rhetorical development of the letter, namely the refutatio-element. According to Bates (1965:64-65), the change in tone is exaggerated.

2. Kümmel (1975:212-213) is convinced that neither historical nor linguistic arguments are sufficient to disprove the integrity of 2 Corinthians.

3. Guthrie (1990:450) points out that the absence of manuscript evidence renders any theory of multiple letters highly unlikely (cf. also Long 2004:3).

All in all, both sides have good arguments in support of their views. In this article, a theory about the origin of 2 Corinthians is proposed, which makes room for arguments from both sides. This theory is based on intrinsic considerations from the letter itself as well as arguments of an historical nature. The theory is not entirely new since it elaborates on a suggestion made by Guthrie (1990:457) that the possibility that 2 Corinthians was not 'composed at a single sitting but was composed with many intervals and pauses deserves further consideration' (cf. also Lamprecht 1999:9).

This investigation is conducted in the following manner: firstly, a survey of the letter's major incoherencies and abrupt transitions are made; secondly, the intrinsic coherence of 2 Corinthians is described in terms of theme words and concepts; and thirdly, a hypothesis for the letter's composition history is formulated. This hypothesis accounts for both the incoherence and unity of the letter.

\section{Abrupt letter transitions and incoherencies}

From the above discussion, the following transitions in 2 Corinthians need to be considered more carefully:

- chapter 2:12-13 and 14 (the transition from verse 13 to verse 14);

- chapter 6:13-14 and 7:1-2 (the alleged interpolation of 6:14-7:1);

- chapter 7:4-5 (the alleged interpolation of 2:14-7:4);

- chapter 8:1 and 10:1 (the transition between chapters 7 and 8 and between chapters 9 and 10; the alleged interpolation of chapters 8 and 9).

\section{The transition of 2 Corinthians 2:12, 13-14}

The first abrupt transition noted by most scholars involves 2:12-13. Weiss (1970:265-267) points to an argument break between 2:13 and 2:14 (cf. also Matera 2003:65). Having mentioned his anxiety in 2:12-13 about not finding Titus, Paul takes leave of the matter in verse 14 and returns to it only in 7:5 - almost 5 chapters later! Weiss puts it as follows: '2:13 and 7:5 fit on to each other as neatly as the broken pieces of a ring' (1970:349; cf. also Thrall 2004:21). From this incoherency was born the theory that 2:14-7:4 was an interpolation (cf. Bornkamm 1962:258-264).
This interpolation theory is countered by the following arguments:

1. Zahn (1906:343) insists that verses 12 and 13 of chapter 2 cannot be separated. He argues that the reference to divine triumph in 2:14 is intended as Paul's own positive answer to his failure in Troas (2:12-13). However, this counter-argument of Zahn still does not explain why Paul, seemingly without any reason, leaves the topic of his search for Titus (2:12-13) and suddenly begins with a discussion of his apostolic ministry (2:14-4:1).

2. The thanksgiving of verse 14 was caused by Paul's joy when he heard from Titus that his 'painful letter' had had positive results in Corinth (Plummer 1925:67). The problem with his argument is that it assumes that verse 14 was written after Paul and Titus had been re-joined. Yet, such a reunion is not reported or even suggested in verses 12-13. To this objection, Plummer (1925:64) answers that perhaps Paul was so overjoyed by the news that he entirely neglected to mention it. However, an argumentum e silentio like this one cannot be convincing.

3. Amidst a number of less forceful arguments referred to by Thrall (2004:22-25), there remains one important matter that should not be overlooked. In 2:12, Paul mentions that the purpose of his visit to Troas was to

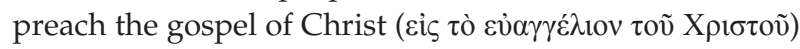
and that, in this regard, a door was opened to him by

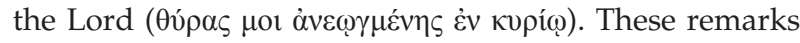
suggest that the apostle's joy in 2:14-17 was not about being re-joined with Titus or about any news he received, but about the door opened to him by the Lord. Thus, it seems that the metaphor of a triumphal entrance in verse 14 links up with that of the open door in verse 12 (cf. Pratt 2000:320). Likewise, Paul's reference to his preaching of the gospel as an aromatic fragrance, which spreads all over, probably links up with his remark in verse 12 that he had arrived in Troas to preach the gospel.

In view of especially the last argument, it is highly probable that verses $12-17$ of chapter 2 forms a logical unit. This unity is supported by the editors of the United Bible Societies' Greek New Testament (1994), who printed 2:12-17 as one pericope. In the New International Version, these verses are also joined with 2:14-3:6 under the heading 'Ministers of the New Covenant'. Such a pericope division favours the above argument that 2:12-13 in fact introduce the topic of Paul's ministry as preacher of the gospel.

More probable is that there is a break in argument between verses 11 and 12. Up to verse 11, Paul was writing about his 'painful visit' to the Corinthians, and then in verse 12 , he abruptly switches to the topic of his arrival in Troas and his anxiety about not finding Titus. So obvious is this break that some scholars have proposed that verses 12 and 13 actually belong elsewhere in the letter (cf. Thrall 2004:181-182). All the efforts of Thrall to bring verses 11 and 12 into harmony seem rather unsuccessful so that it may be concluded with her that the transition from verse 11 to 12 indeed is 'a little abrupt' (Thrall 2004:182). This abrupt transition from 
2:11 to 2:12 has to be accounted for by the theory, which is proposed at the end of this article.

However, taking 2:12-3:6 to be one coherent passage does not solve the problem of the alleged interpolation of 2:14$7: 4$. It only shifts the problem to an earlier part of the text so that the question to be asked is whether the interpolated passage does not actually begin at 2:12 and not at 2:14 as was suspected previously. Naturally, such a shift causes a difficulty for the interpolation theory with its argument that $2: 13$ is continued in 7:5. If the interpolation already starts at verse 12, the argument of the alleged smooth fit between 2:13 and 7:5 (cf. Weiss 1970:265-267) is lost, because 2:11 does not link that easily with 7:5. This difficulty is discussed below in the section that deals with the transition of 7:4-5.

\section{The transitions of 2 Corinthians 6:13-14 and 7:1-2}

The position of the passage of $6: 14-7: 1$ is regarded to be the most problematic as far as the unity of 2 Corinthians is concerned (Lategan 1984:89). It seems that Paul's plea in 6:13 for the Corinthians to open their hearts to him is suddenly interrupted by a passage in which he forbids close association with unbelievers (ärı his plea: 'Make room for us in your hearts.' Accordingly, scholars such as Kirsopp Lake (1919:122-123) are convinced that the passage of 6:14-7:1 is a later interpolation, presumably part of the lost 'painful letter'.

Attractive as this interpolation theory may seem, it causes more problems than it solves. One of the problems is that it needs to be explained why any editor would insert the passage at this peculiar point in the text (e.g. Lategan 1984:90; Plummer 1925:xxiv; Thrall 2004:28). Furthermore, at closer investigation, it proves that 6:14-7:1 is not such a Fremdkörper in the text as it seems at first sight. Matera (2003:160) explains that the passage forms an important part of Paul's argument about the ministry of the new covenant, which he started in 3:1 (cf. also Thrall 2004:472). Amador (2000:101-105) argues that 6:14-7:1 fits in perfectly with the rhetorical strategy which Paul has been following from 5:11 and that it represents a 'call for action' based on the previous argument.

Another point to be considered is that $6: 14-7: 1$ proves to be an integral part of Paul's argument about his ministry of reconciliation, which started in 5:11 and continues until 7:4 (cf. Beale 1989:550-581; Jordaan 1999:483). Based on a thought-structure analysis, ${ }^{1}$ the argument of 5:11-7:4 can be presented as follows in Figure 1.

This schematic summary reveals the following thought pattern of the passage:

1. Firstly, Paul, in line with the rest of the letter, is writing about his apostolic ministry (references to his ministry are marked above by bold lines on the left). In this passage, his ministry is described in terms of God's reconciliation in Christ. Hence, it is a 'ministry of reconciliation'. In his discussion about the ministry of reconciliation, Paul

\begin{tabular}{|c|c|c|}
\hline$\Gamma$ & 5:11-13 & $\begin{array}{l}\text { The background of the ministry of reconciliation: the fear } \\
\text { of the Lord }\end{array}$ \\
\hline & 5:14-17 & $\begin{array}{l}\text { The basis of reconciliation: Christ's love and his sacrifice } \\
\text { by which each of us has become a new creation }\end{array}$ \\
\hline- & $5: 18$ & $\begin{array}{l}\text { The nature and origin of Paul's ministry - reconciliation, } \\
\text { God-given }\end{array}$ \\
\hline & $5: 19$ & $\begin{array}{l}\text { The message of reconciliation A: God reconciled us with } \\
\text { him (indicative) }\end{array}$ \\
\hline & $5: 20-6: 2$ & $\begin{array}{l}\text { The message of reconciliation B: Be reconciled with God } \\
\text { and lead a life of righteousness (imperative). }\end{array}$ \\
\hline E & $6: 3-10$ & $\begin{array}{l}\text { Hardships of Paul's ministry - for the sake of the } \\
\text { Corinthians }\end{array}$ \\
\hline$\Gamma$ & $6: 11-13$ & $\begin{array}{l}\text { The Corinthians' response to his ministry: in the spirit of } \\
\text { reconciliation they should open their hearts to him }\end{array}$ \\
\hline & $6: 14-7: 1$ & $\begin{array}{l}\text { Consequences of reconciliation with God: not to have } \\
\text { fellowship with the ungodly. }\end{array}$ \\
\hline L & $7: 2$ & Open hearts of the Corinthians: Paul's response \\
\hline
\end{tabular}

Source: Coetzee, J.C., 1988, 'Gedagtestruktuurontleding en die eksegese van die Heilige Skrifte', in J.C. Coetzee (red.), Koninkryk, Gees en Woord, bl. 19-37, NG Kerkboekhandel, Pretoria

FIGURE 1: Based on a thought-structure analysis, the argument of 5:11-7:4 can be presented.

follows a logical line of argument. He begins with the background of his ministry, continues to describe the nature and origin of his ministry, follows it up with the hardships, which he experienced in his ministry and finally appeals to the Corinthians to respond to his ministry in loving acceptance.

2. The second line of argument, interwoven with the first, is about God's reconciliation (marked above by arrows on the right-hand side). Once again, the argument follows a logical line: the basis of reconciliation $>$ the message of reconciliation (indicative) $>$ the message of reconciliation (imperative) $>$ the practical consequences of the imperative.

Obviously, there is constant interaction between the two lines described above since the entire passage is about the ministry of reconciliation. At the same time, it is clear that 6:14-7:1 cannot be regarded as an alien element to the text, because it evidently forms an integral part of Paul's argument. Therefore, it proves that the transition from 6:13 to 6:14 and that from 7:1 to 7:2 are not as abrupt as many scholars have claimed.

\section{The transition of 2 Corinthians 7:4-5}

Similar to the argument a break between 2:11 and 12 (cf. the section above dealing with the transition of 2:12-13 and 14), is the discontinuity between 7:4 and 5 . Verse 4 is still part of Paul's argument about the ministry of reconciliation. However, in verse 5, the apostle abruptly switches his attention to the events at his arrival in Macedonia: 'For when we came into Macedonia ...'. Thrall (2004:487) points out that the argument break between verses 4 and 5 is not so abrupt as is suggested by the four-chapter hypothesis.

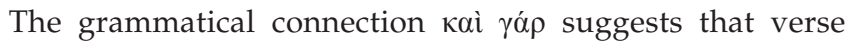
5 actually is explanatory to the previous section, and the participle $\theta \lambda_{\imath} \beta$ ó $\mu \varepsilon v o r$ provides a logical link with the

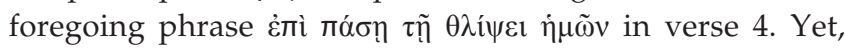
verse 5 seems to take the reader back to 2:13, resuming as if in a ring composition the account of Paul's journey in search of Titus (Matera 2003:171). 
The possibility that $2: 14-7: 4$ is a later interpolation is eliminated by the fact that 2:12-13 ('Now when I went to Troas to preach the gospel of Christ and found that the Lord had opened a door for me ...') forms the introduction to the topic of Paul's ministry. This topic unfolds in 2:147:4. Therefore, the break should not be made between 2:13 and 2:14, but rather between 2:11 and 2:12 (cf. the section above dealing with the transition of 2:12-13 and 14) so that 2:12-7:4 has to be taken as a unit. This conclusion leads to a next question: Should the entire 2:12-7:4 be taken as an interpolation? This question is partially answered by Thrall's (2004:487) information about the grammatical and logical links between verses 4 and 5. Based on a rhetorical analysis, Long (2004:172) suggests that 7:3-16 is a coherent passage, which forms the narration section of Paul's argument and hence cannot be divided. In this section, Paul speaks about the relief he experienced when Titus finally arrived and about the joy caused by the good tidings brought by Titus. Therefore, any suspicion of an argument break in 7:3-16 can be put to rest. If there is any discontinuity in this chapter, it is not to be found in 7:4-5, but rather in 7:2-3.

However, when all is said and done, the mystery of the perfect fit of 2:13 and 7:5 (Weiss 1970:349) remains unsolved. A remark by Grosheide (1959:78) suggests a possible solution. He points out that, when Paul wrote 2:13, he was on his way to Macedonia, not having found Titus ('I had no peace of mind, not finding my brother Titus. So I took leave of them and went on to Macedonia'). Yet, in 7:5-6, Paul and Titus were evidently reunited ('God ... comforted us by the coming of Titus'). Bornkamm (1962:260) remarks that in 7:5-6, Paul does not make any reference to what happened earlier, probably because, in his mind, the new development of Titus' arrival overshadowed all his previous anxieties. Thus, it means that 2:3 and 7:5 is not such a perfect match after all. Although these verses deal with the same issues, the historical setting differs.

\section{The position of 2 Corinthians 8 and 9}

An abrupt change of topic happens at the beginning of chapter 8 and again at the beginning of chapter 10. Up to the end of chapter 7, Paul was describing the relief and joy he experienced at the arrival of Titus. Then, in chapter 8 , he switches to the issue of the collection for the poor in Jerusalem. On this new topic, he dwells until the end of chapter 9 when, once again, he changes the topic abruptly. From chapter 10 almost up to the end of chapter 13, Paul is in earnest defence of his apostolic ministry.

On the basis of these transitions, Weiss (1970:353-357) decided that chapters 8 and 9 are entirely out of place and probably constitute an interpolation in the text. Chapters 8 and 9 are so distinct in contents and tone that Betz (1985:36) concluded that they are separate 'administrative letters' that ended up here in 2 Corinthians. Although not subscribing to the idea of a later interpolated fragment, Minor (2009:186) believes on the basis of the differences between chapters 10 to 13 and the preceding chapters of the letter that these last four chapters of 2 Corinthians ' ... were written after chapters
1-9 when Paul's relations with the Corinthians had taken another sour turn'.

In spite of efforts by scholars such as Plummer (1925:231) and Long (2004:174-178) to prove the opposite, it has to be conceded that chapters 8 and 9 are indeed different from the rest of the letter in that they take leave of the topic of Paul's apostolic ministry and address the issue of the collection for the poor in Jerusalem. Yet, despite this concession, there is no proof for the theory that chapters 8 and 9 were added as interpolations in the text later on (cf. Thrall 2004:36-47). On the contrary, chapters 8 and 9 feature a structure far better than normal interpolated passages (Thrall 2004:39). They are parallel in structure, dealing with the same matters 'item by item':

- 8:1-5 and 9:1-2: The eagerness of the Macedonian churches

- 8:7 and 9:8: The abundance of the contribution

- 8:12-15 and 9:6-7: Equality between contribution and means

- 8:14 and 9:8-11: Rewarding results of the contribution

- 8:16-24 and 9:3-5: An envoy sent ahead.

There are, however, really awkward contradictions between the two chapters. In 8:1-6, Paul exhorts the Corinthians to contribute abundantly, setting the eagerness of the Macedonians as an example. In 9:1-4, he seems to be doing the opposite: he is boasting to the Macedonians about the Corinthians' eagerness to help. In 8:7, he seems to doubt the willingness of the Macedonians. Yet, in 9:2, he expresses his gratitude for their eagerness.

Thus, chapters 8 and 9 do indeed differ in topic from the rest of 2 Corinthians. Yet, there seems not to be enough reason to take these chapters as an interpolation either. Furthermore, it seems that these two chapters, even though they address exactly the same issue, in some respects contain contradictory statements of which the most obvious are the following:

1. In 8:1-5, Paul presents the eagerness of the Macedonians as an example to the Corinthians. In 9:2, he seems to boast about the eagerness of the Corinthians to the Macedonians.

2. From 8:16-24, it seems that Titus has recently left for Corinth to take care of the collection. In 9:3-5, Paul writes as if Titus has been sent by him some time ago, now speaking of his own forthcoming visit.

These features have to be accounted for in the theory, which is presented later on in this article.

\section{The coherence and thought-structure of 2 Corinthians}

In addition to the considerations about transitions in the text of 2 Corinthians, there are some structural characteristics of the letter that should be kept in mind. It should be observed that certain words and phrases are used repeatedly throughout 
the letter. These repetitions mark an overall coherence of the letter. They are the following:

1. Repeated reference is made to the coming and going of Titus. These references appear almost in a fixed pattern in every main section of the letter: 2:12-13; 7:5-16; 8:16-24; $12: 18$. It seems that, in this letter, the matter of Titus' movements was so important that Paul kept on returning to it.

2. Another recurring idea in the letter is that of (self-)

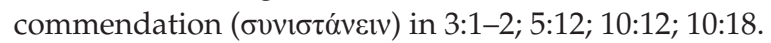

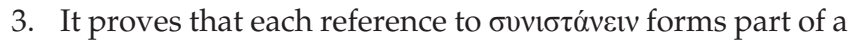
broader section in which Paul is defending his apostolic

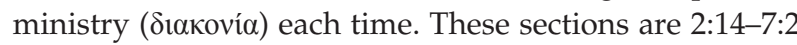

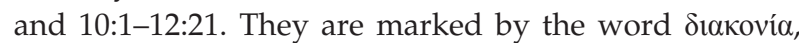

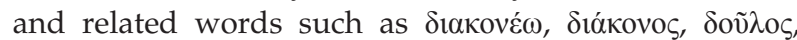
$\pi \rho \varepsilon \sigma \beta \varepsilon v ́ o \mu \varepsilon v, \kappa \eta \rho v ́ \sigma \sigma o \mu \varepsilon v$ and $\lambda \alpha \lambda \circ \tilde{v} \mu \varepsilon v$ are repeated

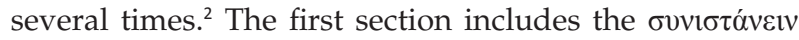
passages of 3:1-2 and 5:12. The second includes the remaining two passages (10:12 and 10:18).

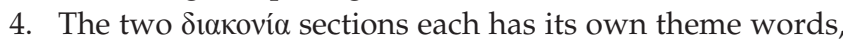
which mark smaller sub-sections:

- In 2:14-7:2, the ministry is related to the old and the new covenant (3:6-18), to the renewal of the old, mortal body (4:7-17) and to reconciliation with God (5:18-7:2). Key expressions are the 'ministry of the new covenant' (3:6), the 'ministry of death' or the 'ministry of the Spirit' (3:7-8) and the 'ministry of reconciliation' (5:18).

- In 10:1-12:21, Paul repeatedly relates his ministry to

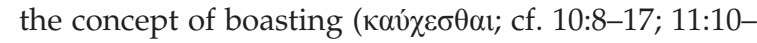
30 and 12:1-11). Semantically, the theme of boasting

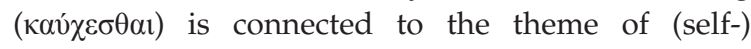

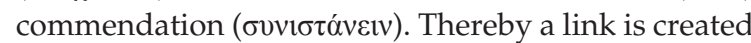
between 2:14-7:2 and 10:21-12:21.

5. In contrast to the idea of self-commendation, the theme of received from God is introduced throughout the letter. This theme is made explicit in $2: 17 ; 3: 5 ; 4: 1-15 ; 5: 5,18 ; 6: 4$; $10: 8,1$. It is interesting that the theme is restricted to the

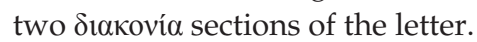

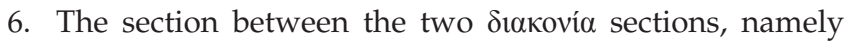
7:3-9:15, is also linked to Paul's ministry by references to

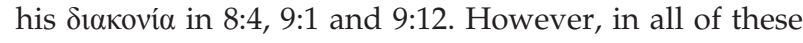
cases, Paul is obviously speaking of his ministry for the (poor) believers in Jerusalem. Accordingly, a new series of theme words appears in 7:3-9:15:

- In $7: 3-16$, the theme word is joy $(7: 4,7,13,16)$. It is connected to comfort $(7: 4,6,7,13)$, and it is contrasted with conflict $(7: 4,5)$ and sorrow $(7: 7,8,9,10,11)$. These repetitions obviously form a link with 1:23-2:11 in which joy and sorrow are also theme words.

- In 8:1-9:15, abundance (rich) and poverty (poor) are frequent opposites: 8:2, 7, 9, 14; 9:6, 8, 11. Another theme in these two chapters is the act of giving or gift (12 times), which should be done willingly (7 times) in love (6 times).

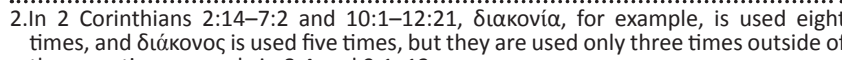
these sections, namely in $8: 4$ and 9:1, 12 .

\begin{tabular}{|c|c|c|}
\hline $1: 12-2: 11$ & \multicolumn{2}{|c|}{$\begin{array}{l}\text { The reaction to Paul's changed travelling plans and the } \\
\text { "painful letter" (theme-words: sorrow, joy, comfort) - }\end{array}$} \\
\hline \multirow[t]{5}{*}{$2: 12-7: 2$} & \multicolumn{2}{|c|}{$\begin{array}{l}\text { Paul's ministry defined (theme words: ministry, } \\
\text { commendation, received from God) }\end{array}$} \\
\hline & 2:12-13 & The coming of Titus (in Troas, not found) \\
\hline & $2: 14-4: 16$ & A ministry of the new covenant \\
\hline & $4: 17-5: 17$ & A ministry of renewal \\
\hline & $5: 18-7: 2$ & A ministry of reconciliation \\
\hline \multirow[t]{5}{*}{ 7:3-9:15 } & \multicolumn{2}{|c|}{ Paul's ministry applied (to the collection for the poor) } \\
\hline & 7:3-16 & $\begin{array}{l}\text { The coming of Titus (arrived in Macedonia) } \\
\text { (theme-words: comfort, joy, sorrow) }\end{array}$ \\
\hline & $8: 1-15$ & $\begin{array}{l}\text { The call for gifts for the poor } \\
\text { (rich, poor, give, willingly, love) }\end{array}$ \\
\hline & $8: 16-24$ & Titus as collector (sent to Corinth) \\
\hline & $9: 1-15$ & $\begin{array}{l}\text { Gratitude for the Corinthians' contribution } \\
\text { to Titus (rich, poor, give, willingly) }\end{array}$ \\
\hline \multirow[t]{5}{*}{ 10:1-12:21 } & \multicolumn{2}{|c|}{$\begin{array}{l}\text { Paul's ministry defended (theme words: ministry, } \\
\text { commendation, boasting, received from God) }\end{array}$} \\
\hline & 10:1-18 & $\begin{array}{l}\text { Paul boasting in the Lord, who gives power } \\
\text { and authority }\end{array}$ \\
\hline & $11: 1-15$ & False apostles boast in themselves \\
\hline & $11: 16-12: 13$ & Paul in himself has nothing to boast about \\
\hline & $11: 14-18$ & Titus Paul's helper in Corinth \\
\hline
\end{tabular}

Source: Coetzee, J.C., 1995, Route map to the books of the New Testament, EFJS, Orkney FIGURE 2: The opening of the letter is taken to be 1:1-2, the introduction 1:3-11, the conclusion 13:1-11 and the ending 13:12-13 (cf. Lategan 1984:93-95).

Keeping in mind the distribution of these theme words, the thought-structure of the letter body of 2 Corinthians (1:12-12:21) can be presented as above (Figure 2) (adapted from Coetzee 1995:40; Guthrie 1990:462-464; Lategan 1984:93-94).

\section{History of composition}

When compared to certain passages in 2 Corinthians, the above evidence tells the story of a letter being written not at a single sitting, but over a period of time at different places - probably on the journey from Ephesus to Macedonia (Philippi). Accordingly, the history of the composition of the letter can be reconstructed as follows.

\section{Corinthians 1:1-2:11 was written en route from Ephesus to Troas}

The first part of the letter was completed by Paul (and his amanuensis) not long after they left Ephesus. It could have been written somewhere en route to Troas or even in Troas itself.

\section{Arguments}

1. When writing about his 'painful letter' (2:1-11), Paul does not refer to the outcome of it, probably because, at the time of writing, he had not yet received any news of it (cf. Grosheide 1959:79; Murphy-O'Connor 1991:25). This suggests a different scenario than in 7:316 where the apostle writes about his abundant joy for the good news that Titus brought about the outcome of the 'painful letter' (7:8-12). Since 1:1-2:11 does not give any suggestion of such joy, Paul could not have written these verses after re-joining Titus in Macedonia. 
He must have written it at an earlier stage when he was still on his way to Macedonia.

2. In 1:8, Paul informs the Corinthians of the hardships he

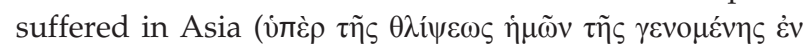
$\tau \tilde{\eta}$ A Áí $\alpha$ ). The exact nature of the $\theta \lambda i \psi 1 \varsigma$ is not mentioned. Nevertheless, the singular form with the article ( $\dot{\eta} \theta \lambda \dot{i} \psi 1 \varsigma$ ) suggests that it was a very specific event. It happened in Asia, which means in Ephesus or shortly after Paul's departure from there. Since Paul felt the need to inform his readers about it, it can be assumed that he had experienced it quite recently, namely after Titus had left his company for Corinth (cf. Grosheide 1959:43; Thrall 2004:114-117). Exactly when Titus left is uncertain, but it can be assumed that it must have been during Paul's stay in Ephesus, probably at about the same time when Timothy and Erastus went to Macedonia (Ac 19:22). If the $\theta \lambda i$ i $1 \varsigma$ refers to the events described in Acts 19:23-40, then Paul wrote these verses soon after he left Ephesus, even before his arrival at Troas. If it refers to some later unreported event (cf. Thrall 2004:116), it could have been written from Troas.

\section{Problem solved}

As already hinted in the first point of the argument above, the differences between 2:1-11 and 7:3-16 are accounted for by this hypothesis for the letter's composition history. Paul wrote 2:11 at a time when his 'painful visit' was still fresh in his memory and when he had not yet received any feedback on his 'painful letter'. Chapter 7:3-16, however, was written a few weeks later from Macedonia when he had received news from Titus about the positive effect of the 'painful letter'.

\section{Corinthians 2:12-7:2 was written en route from Troas to Macedonia}

When Paul left Troas, he took his unfinished letter with him. Then the new turn of events in Troas forced him to add 2:127:2. He seemed to have done so soon after he had left Troas, but before his arrival in Macedonia.

\section{Arguments}

1. Chapter 2:12-13 provides the basic information for this composition hypothesis. At his arrival in Troas, Paul had expected to meet Titus there, but he could not find him. What probably happened is that Paul had sent Titus to Corinth after his 'painful visit'. Titus' instructions were to stay a while and feel the pulse of the Corinthian situation before returning to Paul and then to travel over land via Macedonia and Troas back to Ephesus. Meanwhile, Paul would travel the same route from the other end, from Ephesus through Troas to Macedonia, and from there to Corinth (cf. Grosheide 1959:79; Thrall 2004:186-187). Paul had hoped to meet Titus in Troas, because he was anxious to hear about the outcome of the 'painful letter' (cf. Grosheide 1959:200). However, to his disappointment, Titus had not yet reached Troas. Paul had expected to stay for a while to preach the gospel, because he had

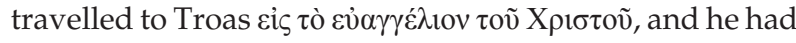
experienced that 'the Lord had opened a door' for him there (2:12). He probably continued to preach the gospel in Troas for some time whilst waiting for Titus. Yet, he was so anxious to see Titus and hear from the Corinthians that he soon decided to leave Troas and travel on to Macedonia (2:13). So eager was Paul to report this new development to the Corinthians that he sat down at the first suitable opportunity after leaving Troas and added 2:12-13 to his letter.

2. At the same time, Paul was so delighted about the door that was opened to him in Troas that he also added 2:1416 to his letter, writing in jubilant tone about his apostolic ministry. Having written these words, he seemed to realise that they could evoke a very negative reaction from his opponents in Corinth. This was so, because he had not yet received any hint of a changed attitude in Corinth. Therefore, in 2:17-7:2, he continued to write about his ministry, but in a different tone. Almost apologetically, he explains the nature of the ministry he had received from the Lord: it is a ministry of a new covenant, a ministry of renewed life, a ministry of reconciliation (cf. the thoughtstructure analysis above). Paul did not keep to a dogmatic discussion about his ministry, but proceeded to apply every aspect of it to the Corinthians' situation (e.g. 3:1-3; $4: 5 ; 5: 11-13 ; 6: 1,11-18 ; 7: 1-2)$.

\section{Problems solved}

1. Firstly, this hypothesis for the letter's composition history explains the abrupt transition from 2:11 to 2:12. The transition was caused by the fact that the apostle did not write the two passages at the same occasion. After Paul had written 1:1-2:11, the events in Troas followed. These events had a definite effect on what he wrote in 2:12-7:2. Thus, the change of tone between the two sections is explained.

2. Secondly, the hypothesis confirms that the transition between 2:13 and 14 is not abrupt at all. Although Paul was disappointed about not having found Titus in Troas (2:13), he was still jubilant about the fact that he could preach the gospel in Troas (2:12). Therefore, the joyous tone of 2:14-16 is not misplaced at all.

3. Also, the difference in tone between $2: 14-16$ and $2: 17-$ $7: 2$ is explained by the above hypothesis for the letter's composition history. When Paul wrote 2:14-16, he was still thinking of the open door he had encountered in Troas. Then his thoughts went ahead to the situation awaiting him in Corinth, and so he wrote 2:17-7:2.

\section{Corinthians 7:3-9:15 was written from Philippi (Macedonia)}

The third part of the letter was probably written from Philippi in Macedonia. Since Philippi was the capital of Macedonia and the former main centre of Paul's ministry in Macedonia (cf. Ac 16:9-40), it is likely that Paul would have chosen it as home base now that he revisited Macedonia during his third missionary journey. Moreover, the willingness of the 
Macedonians towards financial contributions as referred to by Paul in 2 Corinthians 8 corresponds with the general attitude of the Philippians (Phlp 4:10-19). Paul seems to have stayed in Philippi for quite some time, long enough to receive their own contribution, to send off Titus for making new collection arrangements at Corinth and even to receive some report on the willingness of the Corinthians in this respect. During this time, it seems that the apostle had sat down at three different occasions to add new material to his letter.

\section{Arguments}

1. According to 2 Corinthians 7:5, Paul had finally arrived in Macedonia. The journey from Troas to Philippi and even his arrival was not without its hardships, as is evident from verse 5 . About the nature of these hardships, one can only speculate (cf. Thrall 2004:387-388). Nevertheless, the hardships were overshadowed by the apostle's joy about the long-awaited coming of Titus (v. 6). Even more joyous was the good report brought by Titus that the Corinthians had reacted positively to Paul's 'painful letter'. All of this inspired the apostle to write a new section of his letter, namely 7:3-16, in which he expressed his joy about the Corinthians' reaction. That is why these verses abound with references to Paul's joy and comfort (cf. the discussion of the theme words above).

2. After the first excitement of the reunion with Titus, the apostle could settle down and concentrate on the main reason for his journey: the collection for the povertystricken believers in Jerusalem. To his joy, he found that the Macedonians had contributed to this cause beyond expectation (8:3-5), to such an extent that their generosity could serve as an example for the Corinthians (8:1-2). Therefore, Paul decided to send Titus back to the Corinthians so that Titus could prepare their collection in advance (8:6). At this point, Paul probably added chapter 8 to his letter. This could have happened right after Titus had left for Corinth or just before he left. In the latter

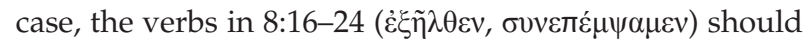
be taken as epistolary aorists (cf. Plummer 1925:247). However, if written before Titus' departure, one could ask why Paul did not send the letter (at least the, by then, finished part) with Titus so that he could deliver it. Therefore, it seems more likely that Paul actually wrote this chapter just after Titus had left.

3. When writing chapter 9, Paul was still in Macedonia. This is evident from 9:2-9. By this time, Titus and his company had in all probability already arrived in Corinth, but Paul himself was already making preparations to depart for Corinth (9:3-4). Therefore, chapter 9 was probably written just before he left Philippi. How long after chapter 8 did this happen? The answer depends on how long Paul's visit to Macedonia lasted, which is difficult to say. ${ }^{3}$ Acts

3.The entire trip from Ephesus via Philippi to Corinth and back to Philippi lasted about ten months. According to 1 Corinthians 16:8, Paul and his company departed from Ephesus right after the Pentecost (early June, AD 56), and on their return from Ephesus right after the Pentecost (early June, $A D 56$ ), and on their return from
Corinth, they remained in Philippi until after the Feast of Unleavened Bread (cf. Ac Corinth, they remained in Philippi until after the
$20: 6)$, which was about middle of April, AD 57. provides no information other than the fact that, before arriving in Corinth, Paul first '... travelled through these parts and gave them much encouragement' (cf. Ac 20:2). It is quite possible that his visit to Illyricum, which he mentions in Romans 15:19, could have taken place during this period. All in all, it seems feasible that Paul's sojourn in Macedonia lasted about two months. Therefore, one could say that Paul wrote chapter 7:3-16, chapter 8 and chapter 9 at more or less one month intervals.

4. The suggested timetable makes it possible that a report about the progress of the collection in Corinth could have reached Paul before his departure from Philippi. Such a development would explain the more positive tone of Paul in 9:2-5 and even in 9:10-15 about the Corinthians' gifts. Otherwise, Paul's boast about the Corinthians can be taken as nothing more than a rhetorical device, as a mere challenge for them to honour. This is a quite feasible suggestion by McCant (1999:89-91).

5. Regarding Paul's claim in 9:2 that Achaia 'has been ready

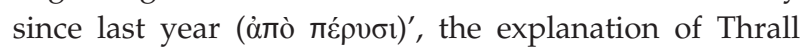
(2004:566) is acceptable, namely that Paul refers to the arrangements of 1 Corinthians 16:1-2, which were made about a year earlier.

\section{Problems solved}

1. Firstly, this hypothesis for the letter's composition history accounts for the abrupt transitions in 7:2-5 and at the beginning of chapters 8 and 9. It is unnecessary to regard one or more of these sections as separate documents, which were later on collected or interpolated into an existing letter.

2. Furthermore, the change of tone between these sections (cf. the section above dealing with the position of chapters 8 and 9) is explained. Paul wrote 7:2-16 when he was in a jubilant mood after the good report he received from Titus. When he wrote chapters 8 and 9, he was deeply involved in the organisation of the collection and therefore these chapters are more 'administrative' in nature. However, chapter 8 was written whilst he was highly impressed with the results in Philippi whereas chapter 9 focuses more on the situation in Corinth.

3. This hypothesis for the letter's composition history offers a solution to the so-called historical discrepancies between 2:12-13 and 7:2-16. The first passage was written before and the latter after Paul had found Titus.

4. The contradictions between chapters 8 and 9 are not completely accounted for by the hypothesis. However, the hypothesis does open up the possibility that the 'contradictions' were caused by the fact that Paul had, in the meantime, received good report about developments in Corinth.

\section{Corinthians 10:1-13:13 was written soon after Paul left Philippi}

Finally, Paul set out from Philippi on the last leg of his journey to Corinth. In all probability, this would last about 
two months. ${ }^{4}$ His third visit to Corinth was now drawing near, a prospect which Paul almost dreaded. From his experience of a few months earlier, he expected to be met with fierce opposition at his arrival. Therefore, he decided to write a final message, because by then, he could no longer delay to dispatch the letter. His arrangements regarding the collection at Corinth were concluded at the end of chapter 9. Then, in chapters 10 to 13 under the enormous strain of a threatening clash in Corinth, he turns to a powerful defence of the authority of his apostolic ministry and the honesty and modesty with which he performed it.

\section{Arguments}

1. In Chapters 10 to 13, Paul mentions his forthcoming visit to Corinth almost four times as often as in all previous chapters. ${ }^{5}$ Twice, he makes special reference of the fact that this will be his third visit to them $(12: 14 ; 13: 1)$. All of these serve as a barometer of the apostle's frame of mind at the time.

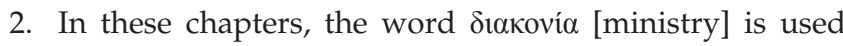
repeatedly, but this time in combination with theme words other than those in 2:12-7:2. Here, Paul is defending his

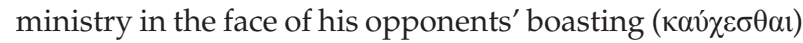

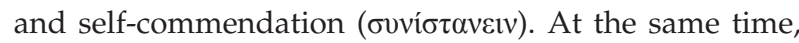
he makes a strong point of the fact that he received his ministry from God himself (cf. the section above dealing with these theme words).

\section{Problems solved}

1. This hypothesis for the letter's composition history explains the sudden change of tone in chapter 10 as observed by most scholars (cf. Grosheide 1959:269; Murphy-O'Connor 1991:99; Plummer 1925:xxvi; Thrall 2004:5-20). The change of tone does not point to a separate letter, because it was only the result of a changed situation and a change in Paul's mood.

2. The hypothesis also offers a solution to the so-called historical discrepancies between chapter 8 and chapter 12 (cf. Thrall 2004:6). When Paul wrote chapter 8, Titus had just left for Corinth, but at the time when he wrote 12:17-18, Titus had already arrived at his destination.

3. Also, the switch from first person plural to the singular in chapters 10 to 13 is explained by this hypothesis. It had to do with the apostle's frame of mind at the time. In chapters 10 to 13, Paul is fending off an expected personal attack by his opponents in Corinth. That is why he switches from a 'we' approach to an 'I' approach. Yet, it does not mean that he bases his defence on his own person or his personal excellence. He is but a humble servant of the Lord (10:7-12; 12:1-10). The authority of his ministry depends entirely on the power and authority of his Sender, the Lord Jesus Christ (10:13-18; 12:10).

\footnotetext{
4.Two months from Ephesus to Philippi, two months in Philippi, two months from Philippi to Corinth, three months in Corinth (Ac 20:3) and one month back to Philippi adds up to ten months (cf. footnote 3 above).

5.Seven times $(10: 1-2,10-11,13-15 ; 12: 14,20,21 ; 13: 1,10)$ compared to $1: 15-17$ and 9:4 in the earlier sections of the letter.
}

\section{Conclusion}

The fact that 2 Corinthians was not composed at a single sitting, but written over a longer period of time, proves to be a feasible working hypothesis for the study of the letter. It provides an explanation for the abrupt transitions and incoherencies in 2 Corinthians without having to question the letter's integrity. In this article, this hypothesis was successfully tested on the contents and structure of the letter. Of course, it remains only a hypothesis, which needs to be tested more thoroughly against external evidence and the intrinsic material of the letter. However, the considerations on which the arguments of this article were based, may serve as a starting point for further investigation.

\section{Acknowledgements Competing interests}

The author declares that he has no financial or personal relationship(s) that may have inappropriately influenced him in writing this article.

\section{References}

Amador, J.D.H., 2000, 'Revisiting 2 Corinthians: Rhetoric and the case for unity', New Testament Studies 46, 92-112. http://dx.doi.org/10.1017/S0028688500000060

Bates, W.H., 1965, 'The integrity of II Corinthians', New Testament Studies 12, 56-69. http://dx.doi.org/10.1017/S0028688500017884

Beale, G.K., 1989, 'The Old Testament background of reconciliation in 2 Corinthians 5-7 and its bearing on the literary problem of 2 Corinthians $6: 1-7: 1^{\prime}$, New Testament Studies 35, 550-581. http://dx.doi.org/10.1017/S0028688500015216

Betz, H.D., 1985, 2 Corinthians 8 and 9, Fortress, Philadelphia. (Hermeneia).

Bornkamm, G., 1962, 'The history of the origin of the so-called Second Letter to the Corinthians', New Testament Studies 8, 258-264. http://dx.doi.org/10.1017/ S0028688500004690

Coetzee, J.C., 1988, 'Gedagtestruktuurontleding en die eksegese van die Heilige Skrifte', in J.C. Coetzee (red.), Koninkryk, Gees en Woord, bl. 19-37, NG Kerkboekhandel, Pretoria.

Coetzee, J.C., 1995, Route map to the books of the New Testament, EFJS, Orkney.

Georgi, D. 1964, Die Gegner des Paulus im 2: Korintherbrief. Studien zur religiösen Propaganda in der Spätantike, Neukirchener Verlag, Neukirchen-Vluyn.

Greek New Testament, 1994, Greek New Testament, ed. B. Aland, M. Black, J. Karavidopoulos, C.M. Martini, B.M. Metzger, 4th rev. edn., Deutsche Bibelgesellschaft and United Bible Societies, Stuttgart.

Grosheide, F.W., 1959, De tweede brief aan die kerk te Korinthe, Kok, Kampen. (Commentaar op het Nieuwe Testament).

Guthrie, D., 1990, New Testament introduction, Intervarsity Press, Illinois.

Hughes, P.E., 1962, Paul's second Epistle to the Corinthians, Eerdmans, Grand Rapids. (New International Commentary on the New Testament).

Jordaan, G.J.C., 1999, 'Die sosiale en praktiese implikasies van 2 Korintiërs 6:14 vir Christene in Suid-Afrika', In die Skriflig 33(4), 469-490. http://dx.doi.org/10.4102/ ids.v33i4.639

Kümmel, W.G., 1972, Introduction to the New Testament, SCM Press, London.

Lake, K., 1919, The earlier epistles of St. Paul: Their motive and origin, Rivingtons, London.

Lamprecht, J., 1999, Second Corinthians, Liturgical Press, Collegeville. (Sacra Pagina, vol. 8)

Lategan, B.C., 1984, '2 Korintiërs', in A.B. du Toit (red.), Handleiding by die Nuwe Testament, vol. 5, bl. 80-94, NG Kerkboekhandel, Pretoria.

Long, F.J., 2004, Ancient rhetoric and Paul's apology, Cambridge University Press, Cambridge. (Society of New Testament Studies monograph series 131).

Matera, F.J., 2003, I/ Corinthians: A commentary, Westminster John Knox, London.

McCant, J.W., 1999, 2 Corinthians, Sheffield Academic Press, Sheffield.

Minor, M.L., 2009, 2 Corinthians, Smyth \& Helwys, Macon. (Smyth \& Helwys Bible Commentary).

Murphy-O'Connor, J., 1991, The theology of the Second Letter to the Corinthians, Cambridge University Press, Cambridge.

Pratt, R.L., 2000, I \& II Corinthians, B \& H, Nashville. (Holman New Testament Commentary) 
Plummer, A., 1925, A critical and exegetical commentary on the second Epistle of St. Paul to the Corinthians, T\&T Clark, Edinburgh. (International Critical Commentary).

Schmithals, W., 1969, Die Gnosis in Korinth: Eine Untersuchung zu den Korintherbriefen, Vandenhoeck and Ruprecht, Göttingen.

Thrall, M.E., 2004, The second epistle to the Corinthians, vol. 1 \& 2, T\&T Clark, London. (International Critical Commentary).
Vielhauer, P., 1975, Geschichte der urchristlichen Literatur. Einleitung in das Neue Testament, die Apokryphen und die Apostolischen Väter, Walter de Gruyter, Berlin.

Weiss, J., 1970, Earliest Christianity: A history of the period A.D. 30-150, transl. \& ed. F.C. Grant, vol. 1 \& 2, Smith, Gloucester, Massachusetts.

Zahn, T., 1906, Einleitung in das Neue Testament, vol. 1 \& 2, Deichert, Leipzig. 